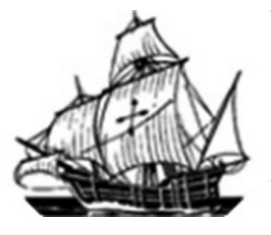

Nau Literária: crítica e teoria de literaturas $\bullet$ seer.ufrgs.br/NauLiteraria

ISSN 1981-4526 • PPG-LET-UFRGS • Porto Alegre • vol. 09, n. $01 ・$ jan/jun 2013

Dossiê: Literatura Infantil e Alteridade no Mundo Lusófono

\title{
Gregório de Matos: o problema, o método e o problema do método
}

\author{
Maria Juliana da Silva Medina
}

\begin{abstract}
Resumo: Confundido com a própria obra - cuja autoria não se pode comprovar, posto que do corpus a ele atribuído não há senão textos apógrafos, o poeta baiano Gregório de Matos Guerra continua suscitando polêmica nos dias de hoje: como tratar o seu legado poético? Depurar o todo até chegar à mens auctoris, como preconiza o método lachmanniano, defendido por Antônio Houaiss, ou, ao contrário, construir uma visão alargada da tradição gregoriana, levando em conta não apenas a matéria poética em si, mas também a cadeia histórica de transmissão e recepção? Considerando estas duas vertentes, e considerando também que a figura controversa de Gregório de Matos Guerra é produto de discursos historicamente construídos, este artigo trata das dificuldades em estabelecer-se o cânon gregoriano e faz um breve percurso pela historiografia literária brasileira, determinante na representação que temos, hoje, do poeta e sua obra.
\end{abstract}

Palavras-chave: cânon gregoriano; apógrafos; método; historiografia literária.

\begin{abstract}
Confused with his own work - whose authorship cannot be proven, once the corpus attributed to him is compounded of apograph texts, the poet from Bahia Gregório de Matos Guerra continues raising controversy nowadays: how to treat his poetic legacy? To refine the whole until arriving to the mens auctoris, as the lachmanniano method recommends, advocated by Antônio Houaiss, or, on the contrary, to build an enlarged vision of the Gregorian tradition, taking into account not just the poetic matter in itself, but also the historical chain of transmission and reception? Considering these two slopes, and also considering that the controversial character of Gregório de Matos Guerra is product of speeches historically built, this article treats the difficulties in establishing the Gregorian canon and makes a brief course for the Brazilian literary historiography, decisive in the representation that we have, today, of the poet and his work.
\end{abstract}

Keywords: gregorian canon; apographs; method; literary historiography. 
Seja pelo anedotário corrente, seja pelo apelido ácido e exato, todos certamente concordarão que boa parte da popularidade de Gregório de Matos e Guerra, o "Boca do Inferno", deve-se à disposição e presteza com que o poeta baiano teria empunhado sua pena impiedosa, o que lhe viria a render não só o apelido, mas também um exército de desafetos entre seus contemporâneos.

No entanto, embora seu nome seja um dos imediatamente lembrados quando se fala de literatura barroca brasileira, há muito mais dúvidas que certezas em torno da vida e da obra do poeta que viveu no século XVII. Não há consenso sequer quanto ao seu ano de nascimento e morte, como se pode perceber pela divergência de datas, se compararmos os textos fundadores. E a rigor, segundo afirma Marcello Moreira, que trabalha sobre uma edição hipertextual de Gregório de Matos e até o ano de 2004 havia editado três códices - Lino de Matos I e II e Lamego, seria problemático até mesmo o estabelecimento do nexo autor-obra:

(...) a tradição crítica, em nosso país, sempre sujeitou a produção poética seiscentista e setecentista brasileira (...) ao poeta Gregório de Matos e Guerra, embora a (...) atribuição haja sido baseada em elementos informativos escassos e de valor duvidoso, como sejam a aposição de um nome (Gregório de Matos e Guerra) à página de rosto dos códices em que foi coligido o conjunto da poesia seiscentista e setecentista baiana e a comprovada documentalmente - existência histórica de um Doutor Gregório de Matos e Guerra. (MOREIRA, 2004, p. 1-2)

Da documentação cartorária localizada por Fernando da Rocha Pérez ${ }^{1}$ em diversos arquivos, Moreira constata tratar-se de matrículas efetuadas pelo poeta na Universidade de Coimbra, bem como de dados sobre o seu primeiro casamento em Portugal, e a define assim: "Documentos que nos transmitem informações pontuais

\footnotetext{
${ }^{1}$ PÉREZ, Fernando da Rocha. Gregório de Matos: uma re-visão biográfica. Prefácio de Antônio Houaiss. Salvador: Macunaíma, 1983, apud MOREIRA, Marcello. Materiam superabat opus recuperação de critérios setecentistas de legibilidade da poesia atribuída a Gregório de Matos e Guerra. In: Org. ABREU, Márcia, SCHAPOCHNIK, Nelson. Cultura letrada no Brasil: objetos e práticas. Campinas: Mercado das Letras, 2005, p. 117.
} 
(...) mas que nada nos dizem, entretanto, sobre sua atividade como escritor, nem nos pintam um retrato, mesmo que em largas pinceladas, do homem Gregório de Matos e Guerra.” (MOREIRA, 2005, p. 117)

Além da documentação cartorária, insuficiente, como se viu, para o conhecimento do homem e do artista, Moreira indica como fonte importante a biografia Vida do excellente poeta lírico, o doutor Gregório de Matos, texto atribuído ao licenciado Manuel Pereira Rabelo, do qual há várias versões, todas produzidas no Setecentos, e por isso mesmo de difícil datação.

A despeito, no entanto, da contribuição de Rabelo, as imprecisões biográficas continuam resistindo e, decorrência delas ou não, as dificuldades para o estabelecimento do cânon gregoriano.

Como todos os códices que nos transmitiram a poesia atribuída a Gregório de Matos e Guerra são de feitura posterior à sua morte, e como todos os exemplares que nos transmitem a Vida foram produzidos no Setecentos, há uma defasagem temporal entre os eventos narrados na Vida e a composição desta última e da tradição codicológica de que faz parte. (MOREIRA, 2005, p. 117)

A se crer no que alega James Amado, que em 1968 editou, segundo afirma sem qualquer veleidade crítica, Gregório de Matos - obra poética, que contém o corpus atribuído ao poeta, ele, James, teria encontrado o texto produzido de próprio punho por Rabelo ${ }^{2}$. E é o texto de Rabelo que tem circulado e sido reproduzido reiteradamente ao longo do tempo, com poucas alterações, acréscimos ou supressões, que melhor nos dá notícia do que hoje se conhece a respeito do poeta.

Terceiro entre os filhos de portugueses abastados, senhores de engenho, Gregório de Matos e Maria da Guerra, Gregório nasceu em Salvador, na Bahia, em 1633 ou 1636, onde passou a infância e estudou no colégio dos jesuítas, mas viveu

2 "Penso ter descoberto o códice manuscrito elaborado pelo próprio licenciado Manuel Pereira Rabelo, o 'biógrafo' do poeta.” (AMADO, 1968, p. 1279) 
boa parte de sua vida em Portugal, de 1652 a 1682, primeiro em Coimbra, onde em 1661 bacharelou-se em direito canônico, depois em Lisboa, onde foi juiz do cível, então já casado com Micaela de Andrade, de família ilustre, de quem ficou viúvo em 1678. Desde Coimbra já gozava de reputação como versejador hábil e de espírito. Suas sátiras temperadas e apimentadas faziam a delícia de seus contemporâneos. Em sua 'biografia', Rabelo conta que Belchior da Cunha escreveu assim a um cavalheiro da Corte, a propósito de Gregório de Matos: “Anda aqui (...) um estudante brasileiro tão refinado na sátira, que com suas imagens e seus tropos parece que baila Momo as chançonetas de Apolo." (RABELO, Manuel Pereira, in AMADO, 1990, p. 1254)

De volta ao Brasil, para onde regressou como clérigo tonsurado a fim de ocupar o cargo de tesoureiro-mor da Sé, negou-se a receber as ordens sacras e a tomar o hábito. Perdeu, então, o cargo de tesoureiro-mor, voltou a exercer a advocacia e casou-se em segundas núpcias com Maria dos Povos, com quem teve um filho. Sua poesia ácida e impiedosa valeu-lhe inimigos entre as autoridades e acabou por ser degredado para Angola, em 1694. Mais uma vez de volta ao Brasil, morreu provavelmente em 1696, no Recife, onde fora morar.

No século XIX veem-se os primeiros esforços para a formação do cânone literário brasileiro, e o nome de Gregório de Matos, quer pela qualidade de seus versos, quer pela produção copiosa, é presença obrigatória em todos os textos, dos quais emerge algumas vezes exaltado, outras tantas deplorado, ao lado tanto de letrados da época, como de anônimos, ou ainda de outros cuja produção literária era pífia, como era então usual dada a inexistência de tradição.

Para que se possa, então, começar a compreender a figura que ainda hoje nos chega controversa, é preciso que se leve em conta que ela é produto de discursos historicamente construídos no esforço para fundação do cânone literário brasileiro, 
que começou com o Cônego Januário da Cunha Barbosa, do qual o que pode ser considerado como o texto inaugural da historiografia literária brasileira, seguido por Joaquim Norberto de Sousa e Silva, João Manuel Pereira da Silva, Carlos Emílio Adet, Francisco Adolfo de Varnhagen, e mais tarde se consolidaram com Ferdinand Wolf, Sílvio Romero e José Veríssimo. Vejamos em breves pinceladas como se forjou a representação de Gregório de Matos na historiografia literária brasileira.

Em Parnaso brasileiro ou "Coleção das melhores poesias dos poetas do Brasil tanto inéditas, como já impressas", obra em dois tomos organizada e editada entre 1829 e 1831, inspirada no Parnaso lusitano de Almeida Garret, com "o fim de tornar ainda mais conhecido no mundo literário o gênio daqueles brasileiros, que, ou podem servir de modelos, ou de estímulo à nossa briosa mocidade" (BARBOSA, Januário da Cunha, in ZILBERMAN; MOREIRA, 1998, p. 84), o Cônego Januário da Cunha Barbosa inclui “A três enforcados, dois negros e um mulato", "Retrato de uma personagem" e "Sátira aos costumes da Bahia", além de dois sonetos, uma glosa e duas décimas.

Joaquim Norberto de Sousa e Silva, por sua vez, publica seus próprios poemas, dez anos mais tarde, pela Tipografia Francesa, do Rio de Janeiro, em Modulações poéticas, que dedica a Januário da Cunha Barbosa, seu protetor, e que é precedido, como em Garret, de um "Bosquejo da história da poesia brasileira", texto este que já havia sido publicado um ano antes, em 1840, e que é reeditado sem grandes alterações, exceto atualizações, quando se fizeram necessárias. É esta segunda versão que Zilberman e Moreira publicam em $O$ berço do cânone: textos fundadores da história da literatura brasileira.

A Gregório de Matos, Joaquim Norberto dedica um parágrafo, no capítulo II, "Primeira Época - Desde o Descobrimento do Brasil até Fins do Século XVII", que 
transcrevemos a seguir, e no qual já se vê a manifestação de um juízo não só a respeito do valor literário da produção atribuída ao poeta baiano, mas também quanto à sua conduta pessoal:

Após este [Jorge de Albuquerque, a quem Joaquim Norberto vem de mencionar] vem Gregório de Matos, grande satírico que nascera na Bahia, em 7 de abril de 1623, e falecera desgraçadíssimo em Pernambuco, no ano de 1697. Sua vida é um complexo de excessos e extravagâncias, e porventura dramática. Foi prodigioso na sátira, mas ao cabo rara deixou-nos que digna seja de ler-se: obscenidades, frases bordalengas andam de envolta com seus versos: contudo seu estilo é simples e coerente, e isento desses trocadilhos e antíteses, com que os poetas seus contemporâneos borrifaram suas obras, pois que não era para afetações, mas todo natureza, todo satírico, se bem que infelizmente um satírico todo indecência. As sátiras Os costumes da Bahia e $O$ retrato de um personagem; os epigramas $O$ músico espancado e $O$ livreiro golotão, são as composições que ler-se podem, que ainda assim seus senões têm que se lhes note. (ZILBERMAN; MOREIRA, 1998, p. 109)

João Manuel Pereira da Silva ocupou-se também de Gregório de Matos. Após o lançamento do primeiro tomo do Parnaso brasileiro, em 1843, foi saudado pelo crítico Santiago Nunes Ribeiro na Minerva brasiliense pelo mérito de ter vulgarizado "as cópias de muitas das mais belas produções de poetas nacionais, algumas das quais são escassas ou adulteradas em manuscritos e confinadas em raros exemplares" (ZILBERMAN; MOREIRA, 1998, p. 148), mas criticado por não ter apresentado muito progresso em relação à obra homônima de Januário da Cunha Barbosa:

Ela peca pelo defeito oposto àquele que se notou nos cadernos que com título idêntico publicara o Sr. Cônego Januário. Nestes figuram certos versos menos que medíocres que não deviam entrar numa obra semelhante: naquela em vão se buscam certas peças de mérito subido, e que devem ter lugar numa seleção perfeita. (ZILBERMAN; MOREIRA, 1998, p 149)

O primeiro volume do Parnaso brasileiro de João Manuel foi o quarto tomo da Biblioteca dos Poetas Clássicos da Língua Portuguesa, série editada por 
Eduardo e Henrique Laemmert, e dedicou-se à poesia dos séculos XVI, XVII e XVIII. O segundo volume, de 1848, integralmente consagrado ao século XIX, foi o sétimo da coleção.

No primeiro volume, o primeiro poeta selecionado por João Manuel é Gregório de Matos, de quem são publicados os poemas "Sátira. Aos costumes da Bahia" e "Retrato". No capítulo dedicado à "Literatura brasileira do século XVII", João Manuel escreve:

De todos os poetas porém do século XVII foi o mais conhecido e reputado Gregório de Matos, nascido na Bahia em 1623. Sua vida toda de emoções; ora protegido pelas primeiras autoridades, ora por elas detestado e perseguido; duas vezes exilado para Angola, por causa de suas sátiras cruéis, mordentes e ferinas; pobre, miserável, cheio de vícios; tudo concorreu para dele fazer uma celebridade da época. Tinha porém muito espírito e graça; suas sátiras são picantes; e nos seus versos reina uma certa lição do mundo, e de malignidade, que os torna muito agradáveis á leitura: é a causticidade e o sarcasmo elevado ao maior grau. (ZILBERMAN; MOREIRA, 1998, p. 164)

Obra escrita a quatro mãos, em 1844, por Joaquim Norberto de Sousa e Silva, de quem já falamos a propósito de Modulações poéticas, e por Emílio Adet, Mosaico poético publica "Aos vícios", “A D. João de Alencastro", “A três enforcados, dois pretos e um pardo", esta já publicada por Januário da Cunha Barbosa em seu Parnaso brasileiro, e "Aos costumes da Bahia", esta última também publicada por Januário e por João Manuel e mencionada pelo próprio Joaquim Norberto no "Bosquejo".

Sobre o poeta, o comentário é curto: "Gregório de Matos e seus irmãos dãose ao cultivo da sátira, ridicularizam os costumes e usos da época, fazendo o povo rir-se à custa de si mesmo, quais outros Juvenais e Pérsios ${ }^{3} . "$ (ZILBERMAN; MOREIRA, 1998, P. 200)

3 Juvenal e Pérsio, poetas satíricos segundo Zilberman e Moreira. 
Já com Francisco Adolfo de Varnhagen, a abordagem da cena literária brasileira ganha maior amplitude e consistência. Seu Florilégio da poesia brasileira, que por razões que não cabem esmiuçar aqui levou vinte e seis anos para ser concluído, de 1846 a 1872, é considerado referência obrigatória na historiografia da literatura brasileira, "verdadeiro fundador da história da nossa literatura", segundo José Veríssimo (ZILBERMAN; MOREIRA, 1998, p. 212213).

O primeiro dos três tomos da coletânea é dedicado a autores dos séculos XVII e XVIII, todos introduzidos por uma biografia. Os irmãos Matos, Eusébio e Gregório, abrem a seleção e ocupam metade do volume, segundo informam Zilberman e Moreira (1998, p. 217-218), que arrolam nada menos que meia centena poesias atribuídas a Gregório de Matos publicadas por Vanhagen .

Quanto ao caráter do poeta, Varnhagen é pouco condescendente, considerando-o insolente em vez de satírico, maledicente e movido pelo sentimento de vingança contra representantes do poder (ZILBERMAN; MOREIRA, 1998, p. 241). Quanto à poesia de Gregório de Matos, o juízo não é muito melhor:

Matos, pelas tendências do seu caráter, fez-se não discípulo, mas escravo imitador de Quevedo, portanto assim como sucede a este, se muitos lhe acham graça e chiste, outro o acharam em oposição com o decoro de engenho: em vez de senhor e gracioso, o encontrarão truão e chocarreiro; quando quer ser filósofo, o acharão cínico. Como Quevedo, o estilo é cortado e desigual: a par de um belo conceito, traz Matos uma sandice, um disparate, ou uma indecência. Sua imaginação era talvez viva e descuidada. $O$ seu gênio poético faísca, mas não inflama; surpreende e não comove; salta com ímpeto e força, mas não voa, nem atura na subida. (ZILBERMAN; MOREIRA, 1998, p. 242)

Em Ferdinand Wolf e a aurora do romantismo nacional, texto publicado em O Brasil literário (história da literatura brasileira), de 1863, de Ferdinand Wolf, o tradutor e prefaciador Jamil Haddad constata a importância da obra do austríaco para a historiografia literária brasileira, assim como a de Sílvio Romero, História 
da Literatura, que veio depois dela, e prenuncia o aparecimento de um terceiro compêndio.

Foi êste livro o compêndio mais importante entre os que precederam a História da Literatura de Sílvio Romero. (...) Aonde queríamos chegar é que antes do livro de Sílvio havia o de Wolf e agora está se esperando que apareça o terceiro compêndio destinado a substituir Romero. (WOLF, 1995, p. VII)

No capítulo II, que vai da página 28 até a página 44, e que tem o conteúdo anunciado no título "Gregório de Matos, primeiro poeta brasileiro importante; seu irmão Eusébio; Bernardo Vieira Ravasco; Manuel Botelho de Oliveira e outros poetas, até o fim do século XVII. Imitadores servis dos escritores portugueses e espanhóis contemporâneos", Wolf dedica quase uma dezena de páginas à apreciação de Gregório de Matos e de sua obra. Começa por contar-lhe a vida, narrando passagens que são extraídas, algumas, ipsis verbis da Vida do excellente poeta lírico, o doutor Gregório de Matos, da lavra do licenciado Rabelo.

Possuímos de autoria de um dos contemporâneos de Gregório, o bacharel Manuel Pereira Rabelo, uma biografia manuscrita do poeta, na qual se encontra um bom número de anedotas e ditos de espírito que lhe são atribuídos. O mesmo bacharel recolheu também suas obras em quatro grandes volumes manuscritos, divisão projetada pelo próprio autor. (WOLF, 1995, p. 37)

Para compor o retrato que apresenta, Wolf consultou ainda os já citados Januário da Cunha Barbosa, Varnhagen e João Manuel Pereira da Silva, entre outros. Ao mesmo tempo em que lhe louva o gênio, critica-lhe a forma descuidada e o estilo gongórico:

(...) era um poeta nato e com uma necessidade irresistível de provar seu gênio satirico; eis porque suas poesias têm todas um carater mais ou menos acentuado de improvisação, de agudeza, de transbordamentos súbitos; às vezes de uma grande simplicidade, às vezes também muito espirituais. Mas a dicção de Gregório está longe de ser escolhida, a forma é descuidada, embora a versificação seja fácil cai enfim frequentemente no trivial. Com

Nau Literária • vol. 09, n. $01 ・$ Gregório de Matos: o problema, o método e o problema do método 
tudo isso, não se pode desconhecer que tomou por modelos os poetas espanhóis de seu tempo, Lope de Veja, Gongora e sobretudo Quevedo que ele imita tão servilmente, o que se pode provar mediante um cotejo de textos. (WOLF, 1995, p. 38)

Aquilo que a tantos parece ser reprovável em Gregório de Matos, para Sílvio Romero, a cuja obra Haddad refere-se já no texto introdutório ao livro de Wolf, é digno de ser exaltado: "o seu caráter honrado e sua alegria expansiva e saudável" (ROMERO, 1980, p. 374). Em sua História da Literatura Brasileira, Romero reproduz com grandes doses de simpatia, e atualizando-lhes a linguagem, as tantas anedotas correntes sobre o poeta, já narradas pelo licenciado Rabelo, em quem francamente inspirou-se. Mas é sobretudo quando trata da poesia que Romero inova e distingue-se dos que o antecederam, reconhecendo em Gregório de Matos não só "amostras de belo lirismo", mas principalmente o traço puramente brasileiro de afirmação da nacionalidade:

(...) é pelo lado humorístico e satírico que o baiano foi um fator nacional. Aí dá ele entrada a certos termos puramente brasileiros e emprega um torneio de linguagem inteiramente popular. Apreciam-se, lendo as suas sátiras escritas no Brasil, quatro fatos característicos: - a diferenciação já crescente da maneira brasileira de manejar a língua; a tendência de ridicularizarem-se entre si, que pronunciadamente animava as três raças formadoras de nossa população; nesta a consciência já clara de ser ela alguma cousa de novo, que não deveria ser sempre a anima vilis das explorações européias, e, finalmente, o descontentamento que lavrava já contra os governos pesados e ásperos da metrópole. (ROMERO, 1980, p. 379-380)

Em Romero, a poesia de Gregório de Matos ganha ainda mais cores quando comparada a de outros poetas que participam do mesmo capítulo II - "Escola baiana - cronistas, oradores e poetas do século XVII”. A evidência salta aos olhos, por exemplo, ao ler-se o comentário de Romero (1980, p. 383) para o fragmento de

\footnotetext{
4 "Todos estes tópicos são amostras de belo lirismo; nem há outro poeta que se avantaje por esta face, no século XVIII, dentre os de língua portuguesa, a Gregório de Matos”. (Romero, 1980, p. 379)
} 
Ilha da Maré, de Manuel Botelho de Oliveira: "Isto é de uma sensaboria privilegiada; não tem rivais"

As tintas simpáticas com que Romero pinta o poeta não encontram equivalência em José Veríssimo, muito mais severo na avaliação que faz, tanto do homem como do poeta:

Enganaram-se redondamente os que pretenderam fazer dele ou quiseram ver nele um precursor da nossa emancipação literária, cronologicamente o primeiro brasileiro da nossa literatura. É de todo impertinente supor-lhe filosofias e intenções morais ou sociais. É simplesmente um nervoso, quiçá um nevrótico, um impulsivo, um espírito de contradição e denegação, um malcriado rabugento e malédico. (VERÍSSIMO, 1981, p. 81)

Além da opinião pouco elogiosa sobre o poeta, Veríssimo também discute e põe em xeque a atribuição de autoria:

Não se limitava a versejar por sua conta, se não que fazia versos para outros. Como se fosse de fato quem satíricos e malédicos mais e melhor os fazia, atribuíam-lhe quantos neste gênero apareciam, de autoria desconhecida. Não é, pois, improvável que dos existentes com o seu nome, os haja que não sejam seus. (VERÍSSIMO, 1981, p. 80)

Confundido com a própria obra, cuja autoria não se pode provar, posto que do corpus a ele atribuído não há mais que textos apógrafos, dado como autor de poemas que provavelmente não tenha escrito, tomado ora por devasso incorrigível, ora por homem de espírito agudo, segundo Romero (1980, p. 382) "genuíno iniciador de nossa poesia lírica e de nossa intuição étnica", Gregório de Matos oscila ao sabor dos juízos críticos que lhe são imputados. Positivos ou negativos, mas jamais indiferentes.

Tais contradições são perceptíveis neste breve percurso pela historiografia literária brasileira que, embora resumido, deixa transparecer o quão determinantes 
foram e continuam sendo os discursos construídos ao longo do tempo, na elaboração e na representação que temos, hoje, de Gregório de Matos e da sua obra.

Pela inegável importância de um autor cuja obra é ainda tão pouco conhecida e tão pouco estudada na história da literatura brasileira, em Tradição $e$ problemática de Gregório de Matos, Antônio Houaiss (HOUAISS in AMADO, 1990, v. II, p. 1273-1278) suscita questões que apontam para a necessidade de darse a lume a edição crítica do poeta baiano. A discussão provocada pelo filólogo é pertinente e oportuna, mas eivada de dificuldades, tanto no que respeita à reconstituição fidedigna de sua biografia, como no que respeita ao estabelecimento do corpus da sua produção poética.

A obra de Gregório de Matos, como se sabe, subsiste em manuscritos apógrafos e, como lembra Moreira, todos os códices que nos transmitem a poesia atribuída a ele são de feitura posterior à sua morte. Assim, a superação destas dificuldades, com a conseqüente fixação do cânon gregoriano seria a condição primeira para a edição crítica da sua obra, como advoga Houaiss, legitimando-o definitivamente como representante de uma literatura autenticamente brasileira, como querem uns, entre os quais, ainda segundo Houaiss, se perfilham Araripe Júnior, Sílvio Romero, Machado de Assis, Ronald de Carvalho, Graça Aranha, Afrânio Peixoto, Constâncio Alves, Xavier Marques, Pedro Calmon, Homero Pires, Clóvis Monteiro, Vale Cabral e Segismundo Spina, entre outros, ou, ao contrário, condenando-o a papel secundário no panorama literário, como querem seus detratores, entre eles Francisco Adolfo Varnhagen, José Veríssimo, João Ribeiro, Sílvio Júlio, Oscar Mendes e Paulo Rónai.

Sem esse texto, sem seu cânon, lavra o maior descompasso no julgamento crítico desse autor - ficando em suspenso o mérito e procedimento de quantos se alinham em favor da tese de que se trata de venerável figura de nossa literatura barroca, bem como de quantos 
de que se trata de secundária figura, a que faltaram honestidade intelectual, originalidade criadora e surto poético de um modo geral. (HOUAISS in AMADO, 1990, v. II, p. 1273)

Juízos polêmicos à parte, e reconhecida a lacuna existente na historiografia literária brasileira no que diz respeito a Gregório de Matos, Houaiss prescreve: "Há (...) que penetrar o material disponível, a fim de sobre ele firmar um julgamento metodologicamente acertado." (HOUAISS in AMADO, 1990, v. II, p. 1274) A empreitada, vê-se desde logo, é de monta, e exigiria, segundo Houaiss, o concurso de especialistas capazes de dar conta do farto material que encontra-se disperso em códices e acervos diversos.

Como tarefa para um só indivíduo, a edição crítica parece cometimento excessivo (...). A pessoa que chamasse a si essa (...) tarefa teria que ter qualificações múltiplas (...). A pessoa em causa deveria ter uma base filológica segura, uma cultura literária excelente (...), com certo nível de especialização que abarcasse o fenômeno literário ibérico (...) e românico, uma boa formação histórica (...) - escusando lembrar certos pormenores de formação, como a capacidade segura de ler apógrafos nos manuscritos do século XVII (...) e um estreito conhecimento de ecdótica (...), e uma visão da problemática específica para o caso vertente. (HOUAISS in AMADO, 1990, v. II, p. 1276)

Houaiss constrói um roteiro minucioso para aqueles estudiosos que, capazes de preencher os requisitos acima, estejam dispostos a dedicar-se "única e exclusivamente ao cometimento [da edição crítica], durante cerca de dez anos" (HOUAISS in AMADO, 1990, v. II, p. 1276), e, embora não o diga expressamente ao longo do ensaio, pode-se depreender, considerando-se o passo-a-passo ali descrito, que o filólogo refere-se ao método concebido pelo alemão Karl Lachmann (1793-1851). Conforme Moreira (2004, p. 3),

embora em nenhum dos parágrafos constituintes do texto de Antônio Houaiss seja mencionado o nome do filólogo germânico ou haja referência ao método que leva o seu nome, depreende-se o modus operandi a ser seguido, a partir da exposição dos fins a que almeja a edição crítica e da elucidação dos meios de alcançá-la.

Nau Literária • vol. 09, n. 01 • Gregório de Matos: o problema, o método e o problema do método 
Com efeito, o método que passou-se a conhecer por lachmanniano divide-se em duas partes: a recensão (do lat. recensio) e a emenda (do lat. emendatio) (CAMBRAIA, 2005, p. 51) e pressupõe a recolha, arrolamento e catalogação de todos os testemunhos de um texto, o estabelecimento de um estema, através da classificação genealógica das versões do texto, segundo as cópias, impressões ou edições que teve, e a correção de falhas ou defeitos de natureza variada, inevitáveis no processo de transmissão.

Vejamos o que propõe Houaiss: antes de mais nada, que as pessoas que tomem para si tal empreitada tenham "material de base fidedigna sobre o qual trabalharem" (HOUAISS in AMADO, 1990, v. II, p. 1273-1277). Material esse cuja editoração seria providenciada pela Biblioteca Nacional, pelo serviço de Documentação do Ministério das Relações Exteriores e por centros filológicos e que seria mais tarde objeto de uma edição diplomática, sobre a qual "se debruçassem a erudição profisssionalizada e a amadorística no bom sentido, com o objetivo primacial de se proceder a uma discussão colegiada crítica de autoria” (HOUAISS in AMADO, 1990, v. II, p. 1277), com o fito de buscar respostas às questões assim elencadas:

Quais as peças constantes dos apógrafos que não seriam realmente de Gregório de Matos, com identificação dos verdadeiros autores? Quais as peças que seriam meras traduções? Sendo traduções, quais as que tinham curso como de autores outros, identificáveis? Quais as peças que teriam sido glosas, pastiches, paráfrases, variações, de acordo com os cânones criadores do tempo, identificando-se aos autores e obras e peças fontes? (HOUAISS in AMADO, 1990, v. II, p. 1277)

Logrando-se responder tais questionamentos, chegar-se-ia ao "resíduo irredutível" da produção transmitida de Gregório de Matos. Dessa substância essencial, identificados os textos recorrentes em dois ou mais códices, e 
consideradas suas variantes, poder-se-ia chegar a um arquétipo o mais próximo possível do original. A partir destes recursos, "uma erudição crítica (...) daria a base objetiva para uma aferição de Gregório de Matos, não apenas nos seus aspectos globais de criação, mas também nos pormenores estilísticos". (HOUAISS in AMADO, 1990, v. II, p. 1278)

Tal como a propõe Houaiss, esta aferição teria um caráter depurador, em busca do estabelecimento do stemma codicum, mas ignoraria as circunstâncias e as condições em que foi produzido o corpus atribuído a Gregório de Matos, estas também reveladoras não só do processo de produção, mas também do de recepção. Esta lacuna na reconstituição do ambiente histórico em que foram produzidos os discursos, tanto os do autor como os de seus intérpretes, Roger Chartier a identifica em A ordem dos livros, no capítulo Figuras do Autor:

Quer ignore o autor ou o deixe a cargo de outros especialistas, a história do livro tem sido praticada como se suas técnicas e descobertas fossem irrelevantes para a história dos produtores de textos, ou como se esta fosse destituída de qualquer importância para a compreensão das obras. (CHARTIER, 1998, p. 34)

Ainda com Chartier, pode-se perceber a mudança de paradigma da crítica literária:

Nestes últimos anos (...) assistimos à volta do autor. Tomando distância em relação às perspectivas que concentravam a atenção exclusivamente no funcionamento interno do sistema de signos constitutivos do texto, a crítica literária quis reinscrever as obras em sua própria história. (...) Com a "estética da recepção" visou-se caracterizar a relação de diálogo instituída entre uma obra singular e o "horizonte de expectativa" de seus leitores (...). (...) A significação do texto é assim compreendida como historicamente construída, como produzida no afastamento que separa as proposições da obra - por um lado controladas pelas intenções do autor - e as respostas dos leitores. (CHARTIER, 1998, p. 34-35) 
Chartier desdobra a argumentação, relacionando-a às abordagens propostas pelo new historicism, com a sociologia da produção cultural e com a bibliography, e vê em comum, em todas elas, o propósito de "rearticular o texto ao seu autor, a obra às vontades ou posições de seu produtor", mas ressalva: "É certo que não se trata de restaurar a figura romântica, magnífica e solitária do autor soberano, cuja intenção (primeira e última) encerra $a$ significação da obra, e cuja biografia dirige a escrita em uma transparente imediatez." (CHARTIER, 1998, p. 35)

Marcello Moreira, a quem já vimos solicitando ocasionalmente desde o início deste texto, refuta a tese de Houaiss e propõe outras formas de edição, que levem em conta a historicidade da tradição gregoriana. Senão vejamos:

A crítica literária (...), representada por alguns dos seus membros mais ilustres, perfilha o caminho traçado pelo (...) filólogo [Antônio Houaiss] e abraça a idéia de que, sem a edição crítica do texto gregoriano - a tradição já expurgada de suas impurezas -, é, senão impossível, pelo menos duvidoso chegar à devida apreciação da obra do poeta seiscentista brasileiro, a fim de determinar-lhe a originalidade e o valor. (...) Diante do exposto, cabenos propor formas outras de edição da tradição de Gregório de Matos e Guerra que considerem sua historicidade como elemento a ser preservado durante o labor editorial. (MOREIRA, 2004, p. 14-15)

Tal opção metodológica implica, por exemplo, levar em conta não apenas a matéria poética em si, o corpus depurado, mas principalmente a cadeia histórica de transmissão e recepção, da qual, no caso da poesia de Gregório de Matos, as didascálias e todos os demais índices "legíveis" que compõem o artefato bibliográfico da tradição gregoriana são um forte testemunho. As didascálias, ou epitextos, ensina Moreira (2005, p.124), "servem para intitular os poemas ou para, melhor dizendo, circunscrever-lhes a matéria poética de que tratam".

Inseridas no início de cada poema, as didascálias são consideradas por James Amado uma intervenção do próprio licenciado Rabelo. Em A foto proibida há 300 anos (Notas à margem da editoração do texto - I), texto integrante de Gregório de 
Matos - obra poética, Amado, ao comentar o caráter elogioso da biografia, afirma: “(...) o licenciado busca, ao longo de sua louvação de GM e nas didascálias, algumas preciosas, com que apresenta suas poesias (grifo nosso), dar uma visão 'protetora' do poeta." (AMADO, 1990, v. I, p. 18)

Ou mais adiante, ao justificar as escolhas que justificaram a edição: "Para fixá-la e preservá-la [a imagem do poeta] rearrumei o que está nos códices, utilizando o texto do próprio licenciado e suas saborosas didascálias." (AMADO, 1990, v. I, p. 23)

E por fím, em Notas à margem da editoração do texto - II, ao atribuir a si a descoberta do manuscrito elaborado por Rabelo, Amado (1990, v. II, p. 1280) afirma: "De maior força comprobatória parece-me o fato de fazer o autor do texto referência expressa às didascálias (...) com que apresenta as poesias, estabelecendo que o autor do texto biográfico é a mesma pessoa que elaborou o códice.”

A se adotar a metodologia recomendada por Houaiss, ter-se-ia por produto uma edição crítica fundada na idéia de autor, a qual, depurada a obra de toda e qualquer interferência que se tenha imiscuído nela ao longo do tempo que separa a produção/enunciação do seu registro escrito, conferiria ao leitor contemporâneo, um retrato da vontade autoral. Em lugar de afunilar o percurso, reduzindo o trabalho à busca da mens auctoris, Moreira propõe uma solução diametralmente inversa: construir uma visão alargada da tradição gregoriana, que seja capaz de desvendar justamente tudo aquilo que o método lachmanniano, por força dos seus pressupostos, teria que deixar oculto. Assim, para Moreira, o problema deve ser posto em outras bases: "Como ponderar criticamente a distância que separa o poeta a quem é atribuído o corpus que leva o seu nome e que foi produzido por outrem, décadas após a sua morte, dos artefatos bibliográficos-textuais que constituem a tradição?” (MOREIRA, 2005, p. 118) 
O problema assim enunciado impõe que seja considerado sob a perspectiva da defasagem temporal entre a época da produção do corpus atribuído a Gregório de Matos e a de sua compilação. É aí que ganham relevo não só a Vida do excellente poeta lírico, o doutor Gregório de Matos e as didascálias que a integram, mas também toda a fortuna crítica produzida desde Januário da Cunha Barbosa. Assim, deslocado o foco da figura do autor, privilegia-se a noção de preservação de uma memória a ser construída a partir do "conjunto de práticas e de fazeres consubstanciados nos códices poéticos setecentistas que chegaram até nós" (MOREIRA, 2005, p. 121).

No volume II de Gregório de Matos - obra poética, Amado (1990, v. II, p. 1306-1311) arrola nada menos que dezessete $\operatorname{códices}^{5}$, dos quais alguns apresentam versões ampliadas da 'biografia', como por exemplo "A Vida do Grande Poeta Americano Gregório de Mattos Guerra", do códice Afrânio Peixoto; "Vida do Dr. Gregório de Matos Guerra", do códice Carvalho, além do códice Varnhagen, em que se lê: "Em que no princípio se inclui a sua vida escrita por um amante da sua memória: e depois apurada melhor por outro curioso Engenho".

O códice Asensio-Cunha, que Amado nomeia códice Manuel Pereira Rabelo, e traz uma das versões mais prestigiadas da Vida do excellente poeta lírico, o doutor Gregório de Matos, chega até os dias atuais em quatro volumes e em excelente estado de conservação. É “valioso especialmente pela riqueza de informações contidas nas legendas-título e à margem dos versos" (AMADO, 1990, p. 1310). Amado e Moreira estão de acordo: a Vida não é apenas biografia: é elogio, encômio. “A ‘biografia’ não é biografia”, escreve Amado (1990, p. 1280):

\footnotetext{
${ }^{5}$ Em seu ensaio Tradição e problemática de Gregório de Matos, Houaiss arrola dez códices como sendo os "efetivamente localizados e de comprovação positiva ou negativa fácil".(AMADO, 1990, p. 1274-1275)
} 
(...) Manuel Pereira Rabelo fez um texto polêmico de 'defesa' de seu ídolo Gregório de Matos, vítima das acusações mais demolidoras. (...) Apesar do título do escrito, "Vida do...", a intenção do texto é pouco biográfica (a legenda de GM era popularíssima, todo mundo julgava conhecer o poeta e a novela de sua vida), o que se constitui em elemento a mais para aproximar o códice do licenciado do tempo de vida de GM. O escrito do licenciado objetiva reafirmar a dignidade do poeta e atender ao desejo ingênuo de provar que ele não fora tão mau cidadão quanto se proclamava. (AMADO, 1990, P. 1280)

"A Vida é encômio, memória panegirical", assevera Moreira, que leva adiante a reflexão:

Como elemento textual que compõe um artefato bibliográfico (...) e que proporciona organicidade e coesão internas a esse mesmo artefato (...), a Vida não deve nem pode ser lida separadamente da unidade artefatual de que é elemento constituinte e que é, em suma, uma unidade bibliográfico-textual.

A Vida justifica-se na medida mesma em que ela justifica a construção de um monumento eficiente para a perpetuação de uma memória de que ela faz parte. (MOREIRA, 2005, p. 120)

Como panegírico, a Vida bastaria por si só, posto que contém todos os elementos prescritos pelo gênero. No entanto, paradoxalmente, ela reúne e dá a conhecer a obra atribuída ao encomiado. Tal paradoxo encontra em Moreira (2005, p. 120) a seguinte explicação:

(...) embora suficiente como discurso encomiástico para a promoção do louvor de um poeta, ele [o panegírico] se afirma, no que contradiz a tradição dessa espécie do epidítico, logo nas primeiras linhas, insuficiente para comemorar a excelência de um poeta, pois como declará-la, se não se tornar possível apresentá-la para o ajuizamento dos pósteros?

No século em que viveu Gregório de Matos e nos imediatamente posteriores, a poesia a ele atribuída circulou e foi transmitida de forma dispersa, seja oralmente, seja em suportes precários, como folhas volantes ou mesmo em pedaços de folhas, nas quais se copiavam os textos. "O códice poético é o remédio encontrado por Rabelo e por outros para frear a dispersão", constata Moreira (2205, p. 123). "Há 
como enaltecer o exceler de um poeta se não houver memória de seu poetar?", pergunta ele, que assim responde:

(...) não apenas a Vida, mas também o códice de que a Vida é um elemento constituinte celebram a memória do varão digno de enaltecimento, de fama e glória imorredouras, ao constituí-la textual e bibliograficamente; o códice poético é, por conseguinte, simultaneamente memória e monumento. (MOREIRA, 2005, p. 121)

Desta forma, reunido, transcrito e compilado, o corpus havia de ser organizado internamente, donde o recurso às didascálias e demais notas apostas por Rabelo:

(...) Rabelo dispôs, ao elaborar seu fabuloso códice, de um material fartíssimo e de uma documentação não só farta como legítima, que ele aproveitou amplamente nas didascálias e ainda em anotações à margem dos versos, referindo nome completo, profissão e, às vezes, local de residência de pessoas citadas nas poesias. (AMADO, 1990, p. 1280)

Assim, para além da função delimitadora da matéria poética, as didascálias são uma intervenção, uma chave de leitura que organiza o discurso segundo critérios semânticos e participam da obra de Gregório de Matos, assim como a obra atribuída a Gregório de Matos, embora cronologicamente anterior, participa das didascálias, em mútua reverberação.

A Vida (...) serve de referencial discursivo que emoldura os poemas, no interior das grandes coleções e, simultaneamente, repropõe aos leitores do século XVIII formas de apropriação do corpus enfeixado nos códices, segundo critérios de legibilidade não estranhos aos letrados do período. A Vida, além de encômio, é mediação, em diferentes níveis. É mediação histórica entre um corpus e os leitores do século XVIII e é mediação entre leitores e os poemas reunidos em artefatos. A Vida é, portanto, mais um elemento do códice poético que participa de sua coesão interna. (MOREIRA, 2005, p. 125)

Aqui, estabelecidas as premissas que norteiam um e outro projeto de edição da obra de Gregório de Matos, o de Houaiss e o de Moreira, tendo-se ainda 
considerado a dificuldade, se não impossibilidade, de atribuir-se com absoluta segurança a autoria do corpus a ele atribuído, assim como se tendo constatado, naqueles autores cujos textos revelam como foi escrita a história da literatura brasileira, a mistura de fatos e lendas, sem a qual não há uma boa 'biografia', é necessário que se traga à discussão a análise histórico-sociológica do personagem autor empreendida por Michel Foucault no célebre ensaio $O$ que é um autor?:

Como o autor se individualizou em uma cultura como a nossa, que estatuto the foi dado, a partir de que momento, por exemplo, pôs-se a fazer pesquisas de autenticidade e de atribuição, em que sistema de valorização o autor foi acolhido, em que momento começou-se a contar a vida não mais dos heróis, mas dos autores, como se instaurou essa categoria fundamental da crítica "o homem-e-a-obra". (FOUCAULT, 2001, p. 267)

A análise histórico-sociológica, contudo, não esgota a questão e Foucault aborda a relação do texto com o autor, estabelecendo então a função-autor, cuja existência demonstra com as noções de obra e de escrita.

Um nome de autor não é simplesmente um elemento em um discurso (...): ele exerce um certo papel em relação ao discurso; assegura uma função classificatória; tal nome permite reagrupar um certo número de textos, delimitá-los, dele excluir alguns, opô-los a outros. Por outro lado, ele relaciona os textos entre si. (FOUCAULT, 2001, p. 273)

\section{Continuemos com Foucault:}

É dito (...) que o próprio da crítica não é destacar as relações da obra com o autor, nem querer reconstituir através dos textos um pensamento ou uma experiência; ela deve antes analisar a obra em sua estrutura, em sua arquitetura, em sua forma intrínseca e no jogo de suas relações internas. (FOUCAULT, 2001, p. 269)

\section{Ora, pergunta:}

O que é uma obra? O que é pois essa curiosa unidade que se designa com o nome de obra? De quais elementos ela se compõe? Uma obra não é aquilo que é escrito por aquele que é um autor? (...) Se um indivíduo não fosse um autor, será que se poderia dizer que o que

Nau Literária • vol. 09, n. 01 • Gregório de Matos: o problema, o método e o problema do método 
ele escreveu, ou disse, o que ele deixou em seus papéis, o que se pode relatar de suas exposições, poderia ser chamado de "obra"? Enquanto Sade não era um autor, o que eram então esses papéis? Esses rolos de papel sobre os quais, sem parar, durante seus dias de prisão, ele desencadeava seus fantasmas. (FOUCAULT, 2001, p. 269)

Em Gregório de Matos, que, considerando-se a extensão do corpus a ele atribuído, também escrevia copiosamente, resta o problema da autoria. Em Il libro manoscritto, Armando Pettrucci, a quem Chartier se refere em A ordem dos livros, afirma: "A textualidade perfeita, emanação direta do autor, garantida por sua escrita autógrafa, era (e sempre seria) a garantia de uma legibilidade absoluta para o leitor" (PETTRUCCI, Armando, in CHARTIER, 1998, p. 55). Qual seria a vontade do nosso descuidado poeta, emanação direta da sua intenção, essa, infelizmente, talvez nós, leitores, nunca venhamos a saber. Com efeito, o licenciado Rabelo, a quem coube o acaso de situar-se cronologicamente mais próximo do autor, já escrevia na introdução da sua 'biografia': "Abreviarei a vida de um poeta pouco cuidadoso de estendê-la nos espaços da eternidade que lhe franqueou as portas" (AMADO, 1990, p. 1251).

O recurso a uma crítica preocupada em extrair o resíduo irredutível da obra gregoriana, resumindo-se a perseguir aquilo que seria a vontade autoral, a mens auctoris, daquele que, não se sabe por qual razão, não teve o cuidado de deixar nenhum texto autógrafo, é, de certa forma, trair essa mesma vontade autoral.

Retomemos Foucault:

Dentre os milhões de traços deixados por alguém após sua morte, como se pode definir uma obra? A teoria da obra não existe, e àqueles que, ingenuamente, tentam editar obras falta uma tal teoria e seu trabalho empírico se vê muito rapidamente paralisado. (...) Percebe-se que abundância de questões se coloca a propósito dessa noção de obra. De tal maneira que é insuficiente afirmar: deixemos o escritor, deixemos o autor e vamos estudar, em si mesma, a obra. A palavra "obra" e a unidade que ela designa são provavelmente tão problemáticas quanto a individualidade do autor. (FOUCAULT, 2001, p. 270) 
Segundo James Amado, o licenciado Rabelo, ao elaborar a 'biografia' do poeta, teria tido à sua disposição documentação não só farta como legítima, embora não mencione a natureza desta documentação, que teria aproveitado amplamente nas didascálias e em demais anotações à margem dos versos apógrafos. Como definir, então, a obra de Gregório de Matos entre os traços deixados por ele após a sua morte, sem considerar também as intervenções do seu 'biógrafo', assim como os discursos que sobre ele vêm sendo construídos desde Januário da Cunha Barbosa e seu Parnaso brasileiro ou "Coleção das melhores poesias dos poetas do Brasil tanto inéditas, como já impressas"? "Uma obra não é aquilo que é escrito por aquele que é um autor?”, pergunta Foucault (2001, p. 269). A esta, poder-se-ia acrescentar ainda uma pergunta: uma obra não é também aquilo que é escrito sobre aquele que é um autor?

\section{Referências}

AMADO, James. Gregório de Matos - obra poética. Rio de Janeiro: Record, 1990.

CAMBRAIA, César Nardelli. Introdução à crítica textual. São Paulo: Martins Fontes, 2005.

CHARTIER, Roger. A ordem dos livros - leitores, autores e bibliotecas na Europa entre os séculos XIV e XVIII. Brasília: Editora Universidade de Brasília, 2a edição, 1998.

FOUCAULT, Michel. $O$ que é um autor? In: Estética: literatura e pintura, música e cinema. Organização e seleção de textos, Manoel Barros da Motta. Rio de Janeiro: Forense Universitária, 2001.

MOREIRA, MARCELLO. Materiam superabat opus - Recuperação de critérios setecentistas de legibilidade da poesia atribuída a Gregório de Matos e Guerra. In: ABREU, Márcia, SCHAPOCHNIK, Nelson. Cultura letrada no Brasil: objetos e práticas. Campinas, SP: Mercado das Letras, 2005. 
MOREIRA, Marcelo. Teorias editoriais e a produção de uma edição hipertextual da tradição de Gregório de Matos e Guerra. Texto apresentado no I Seminário Brasileiro sobre Livro e História Editorial. Rio de Janeiro: Casa de Rui Barbosa, 2004.

ROMERO, Sílvio. História da Literatura Brasileira. $2^{\circ}$ volume, Contribuições e estudos gerais para o exato conhecimento da literatura brasileira. Rio de Janeiro: Livraria José Olympio Editora, $7^{\mathrm{a}}$ edição organizada e prefaciada por Nelson Romero. 1980.

VERÍSSIMO, José. História da Literatura Brasileira: de Bento Teixeira, 1601, a Machado de Assis, 1908. Brasília: Editora Universidade de Brasília, 4ª edição, 1981.

WOLF, Ferdinand. O Brasil literário (história da literatura brasileira). Tradução, prefácio e notas de Jamil Almansur Haddad. São Paulo: Companhia Editora Nacional, 1955.

ZILBERMAN, Regina, MOREIRA, Maria Eunice. O berço do cânone: textos fundadores da história da literatura brasileira. Porto Alegre: Mercado Aberto, 1998. 